\title{
Community College Bestiary
}

\author{
JOHN S. SCHARF*
}

There are many species in the bestiary of Canadian two-year institutions. Each of us could develop our own list and the possibilities are fascinating: dinosaur, mouse, shark, hyena, eagle, elephant, mole, donkey, snake. Tempting as it would be to elaborate upon all the foregoing, this brief visit to the zoo will be restricted to only two of our familiar denizens: beavers and coyotes. After all, why look to exotica when two of our institutional species are indigenous.

The most numerically prominent of our species is the beaver, the quintessence of our Canadian two-year institutions. The beaver is industrious, pragmatic and traditional. The beaver only changes to keep things the same. When a family of beavers was released from a European zoo after eight generations without trees or lakes or running water, they immediately set about cutting trees, building dams, and constructing houses.

Coyotes are an entirely different breed. They are among the prime entrepreneurs of nature, always alert to the next opportunity. Change the situation and coyotes adapt. Chase them out of their favoured habitat and they prosper somewhere else. Consequently, coyotes, like crows and rats, continue to thrive as man continually spreads across the planet.

The beavers in our institutions are solid and reliable: they put in a good day's work, co-operate, don't ask too many questions, and - above all - are predictable. The beavers are as solid and enduring as are the buildings they work in. They labour on faithfully, earn their pay each day, and they survive. They have arrived.

The coyotes are not very predictable, as they may do great things one day and less than that the next. They march to their own drummer at least part and perhaps most of the time. Sometimes, they discover new pathways to established goals and other times, they discover new goals. While the beaver will virtually always travel to the traditional goal in the established way, the coyotes in our midst, through boredom, a sense of adventure, or some perceived perversity or deficiency of character, like to find new ways of doing things and new things to do. Coyotes have not arrived. They are always in the process of getting somewhere else.

Thus, we have two polar types of employees in our two-year institutions. The philosopher might see it thus, with apologies to Isiah Berlin: the beaver knows one big thing, the coyote knows many little things. The administrative

*Chairman, Development Division, Saskatchewan Continuing Education, Kelsey Institute of Applied Arts and Sciences. 
analyst might see it another way. The beaver prefers little or no risk and will accept a low pay-off; the coyote prefers the high pay-off and will accept significant risk to achieve this.

How many beavers and coyotes does your institution have? How many should it have? There is no magical formula or ratio suggested here, but a couple of basic principles can be enunciated: too many coyotes will make for a very volatile organization and too few will result in an apathetic one. The former condition, in an established organization, is virtually inconceivable. A large number of coyotes are often found in new organizations, but their numbers - in a relative sense at least - begin to decline as the organization ages. The latter condition, the shortage of coyotes, is far more likely. The danger for a mature organization is that all the coyotes will be driven out or that they will be forced to masquerade as beavers. With no coyotes, other than the closet variety, the institu tion becomes a very safe and comfortable place. In a predictable environment - that is, a constant number of students wishing to enroll in the proper proportion in existing programs, a budget increased annually at the real inflation rate faced by educational institutions, and other similar conditions - there could be a case made for an institution populated entirely by beavers.

However, if the environment was ever so predictable, it is not so now, nor is it likely to be in the future. Most analysts refer to the environment today as turbulent. The two-year institutions, far more than universities or schools, operate in a turbulent environment. For example, industry-based training is threatening to capture much of the growth which the two-year institutions had been counting on for the 1980's. Coyotes in business and industry can mount programs in a few months, while beavers in post-secondary departments in government and in instructional institutions take years.

Warren Bennis, in his Unconscious Conspiracy: Why Leaders Can't Lead (1976) stated that most organizations attempt to drive their coyotes out, even when this is at the risk of obsolescence. Coyotes that are sensitive to the environment, who have the capacity to be sensors or scanners, are often perceived by beavers as being mischevious or as troublemakers. Beavers may force coyotes into marginal and isolated positions which, in turn, may lead to increased deviancy and perhaps ultimately into disruptive behaviour.

Virtually no organization has too many coyotes, as the available territory can only support so many entrepreneurs. As previously pointed out, the opposite is common, and usually leads to institutional rigor mortis. There will virtually always be a few coyotes found in developmentally oriented positions, such as policy and planning, institutional research, and continuing education. These positions, as I argued in "Community College Radar" (1982), require risk takers by the very nature of the roles; and, consequently, an environment to support them must be established to ensure the continuity of these functions.

Jay Galbraith (1982) took this argument one step further in "Designing the Innovating Organization", arguing for the establishment of an entirely separate structure for coyotes within an organization. Galbraith stated that a productive 
organization must innovate, and this is far more likely to be achieved within an organization that has planned for it. This is best achieved by separating the innovators - independent, irreverent, and sometimes ornery generalists - from the operators, who would otherwise be inclined to crush the innovators. This separation can be physical, financial or organizational and should include the right kind of managers, appropriate incentives and dual career ladders to ensure that the coyotes are retained.

This concept of separating the creative part of the organization from the operating has been suggested by other writers. Baldridge (1980:132) argued for a 'security blanket' for innovative projects. His research on successful innovation indicated that it must be sheltered from senior administrative beavers. March (1981) observed that organizations are intrinsically altruistic in that they often support a kind of innovative underground which is a nuisance in the short term in that particular organization but which is critical to the long term success of the larger system to which that organization belongs. March (1981: 572-73) stated that the organizational 'foolishness' of creativity and change is often protected from the 'rationality' of normal operating procedures through a variety of structural and organization systems.

Probably few of our colleges are structurally sophisticated in the manner that Galbraith and Balderson have advocated, but the concept of foolishness as articulated by March may describe the kind of terrain that prevents the coyote from becoming an endangered species in our institutions. Indeed, in the conventional bureaucracies that characterize most of our institutions, coyotes are found in various instructional, support, and administrative positions.

The least likely place to find a coyote, other than the closet variety, is in a senior line position. The whole selection process, as research has shown, is structured to minimize the possibility that a coyote may emerge in one of these positions. For beavers in junior positions, safety, comfort, permanence and freedom from responsibility are best ensured by fellow beavers in charge. Coyotes are too unpredictable, and may even come up with some plan to drain the pond.

Educational institutions are not the engines of society; in reality, they act more like the brakes. Furthermore, of the major categories of educational organizations, the two year institution has the most conservative mandate. Consequently, it is not surprising to find a predominance of beavers in these institutions. On the other hand, the propensity of beavers to accept the low pay-off in order to not have to live with risk is ultimately self-defeating in a turbulent world. A judicious mix of beavers and coyotes is required and the predominent beavers must come to understand that their own long term security is dependent on having some entrepreneurs in their midst.

Perhaps the difference between beavers and coyotes can best be summed up in how they utilize one specific part of their anatomy. The beaver hasn't much of a neck anyway, and feels most comfortable with his head down. The coyote has a prominent neck, and figures if there is any purpose in having such a neck, surely it is to stick it out. 
76 John S. Scharf

\section{REFERENCES}

Baldridge, J.V. Managerial Innovation: Rules for Successful Implementation. Journal of Higher Education, 51, 2, 117-134.

Bennis, W. The Unconscious Conspiracy: Why Leaders Can't Lead. New York, AM ACOM, 1976.

Galbraith, J.R. Designing the Innovating Organization, Organization Dynamics, Winter, 5-25, 1982.

March, J.G. Footnotes to Organizational Change. Administrative Science Quarterly, 26, 563-577, 1981.

Scharf, J.S. Community College Radar. Community College Review, Spring, 36-41, 1982. 